Supporting Information

\title{
DNA Microgels as a Platform for Cell-free Protein Expression and Display
}

Jason S. Kahn, ${ }^{\dagger}$ Roanna C.H. Ruiz, ${ }^{\ddagger}$ Swati Sureka, ${ }^{\dagger}$ Songming Peng, ${ }^{\dagger}$ Thomas L.

Derrien, ${ }^{\dagger}$ Duo An, ${ }^{\dagger}$ and Dan Luo*,+,

${ }^{\dagger}$ Department of Biological and Environmental Engineering, Cornell University, Ithaca, NY14853USA.E-mail: dl79@cornell.edu

${ }^{*}$ Department of Biomedical Engineering, Cornell University, Ithaca, NY 14853, USA.

$\S$ Kavli Institute at Cornell for Nanoscale Science, Cornell University, Ithaca, $N Y$, 14853, USA.

Table of Contents:

(1) Plasmid map

(2) Preparation of P-gel microgels

(3) Preparation of lysate

(4) wtGFP standard

(5) Maleimide-C3-NTA functionalization of oligonucleotides

(6) FACS control

(7) Psoralen crosslinking 


\section{(8) Section 1 - Plasmid map}

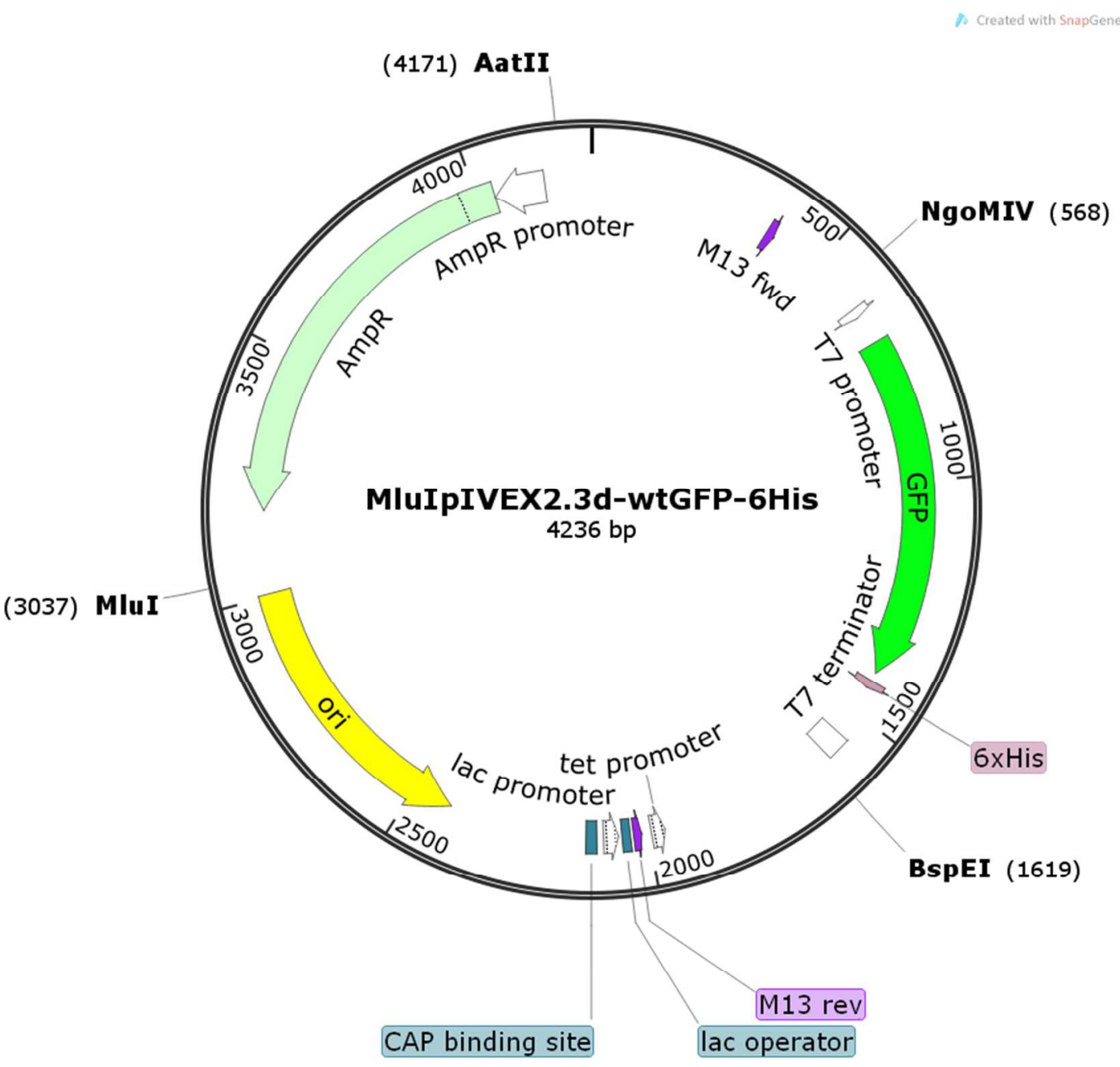

Figure S1. Plasmid map of the pIVEX2.3d-wtGFP used throughout the study. 


\section{Section 2 - Preparation of P-gel microgels}

Table S1 provides an overview of the aqueous inputs and Table S2 provides resulting gel microgel sizes as a result of differing flow rate ratios between the aqueous (combined flow) and oil phase. We used a 3:1 ratio, as the smaller size was more appropriate in producing cell-sized gels, in addition to the higher homogeneity in the droplets.

Table S1. Aqueous inputs for the microfluidic production of P-gel microgels

\begin{tabular}{|l|c|l|c|}
\hline \multicolumn{2}{|c|}{ Syringe 1 } & \multicolumn{2}{c|}{ Syringe 2 } \\
\hline X-DNA $(300 \mu \mathrm{M})$ & $83.33 \mu \mathrm{L}$ & NEB T4 Ligase $(2,000 \mathrm{u} / \mu \mathrm{L})$ & $0.8 \mu \mathrm{L}$ \\
\hline Linear Plasmid $(1500 \mathrm{ng} / \mu \mathrm{L})$ & $15.53 \mu \mathrm{L}$ & Cutsmart Buffer $(10 \mathrm{X})$ & $20 \mu \mathrm{L}$ \\
\hline Tris-NaCl Buffer $(10 \mathrm{mM})$ & $1.14 \mu \mathrm{L}$ & ATP $(10 \mathrm{mM})$ & $30 \mu \mathrm{L}$ \\
\hline & & NF- $\mathrm{H}_{2} \mathrm{O}$ & $49.2 \mu \mathrm{L}$ \\
\hline Total & $100 \mu \mathrm{L}$ & Total & $100 \mu \mathrm{L}$ \\
\hline
\end{tabular}

Table S2. Mean diameter and standard deviation of DNA microgels using a $1 \mu \mathrm{m}$ channel width and either a 1:1 (oil:aqueous phase) or 3:1 flow rate.

\begin{tabular}{|c|c|c|}
\hline & 1:1 Flow Ratio & 3:1 Flow Ratio \\
\hline Mean $(\boldsymbol{\mu m})$ & 38.03 & 24.77 \\
\hline SD $(\boldsymbol{\mu m})$ & 2.56 & 1.64 \\
\hline
\end{tabular}

For gel formation, we did not use stock ligase buffer as provided by New England Biosciences (NEB) or Promega, but rather CutSmart Buffer from NEB. This change in protocol was enacted due to the presence of dithiothreitol (DTT) in the buffer, which can interfere with downstream applications of the gels. More specifically, protein display applications can be significantly hindered, as DTT can reduce divalent cations that will participate in NTA-metal ion chelation common in His-tag binding. As there 
is no ATP present in the CutSmart Buffer, this component is added to reach to 1.5 $\mathrm{mM}$.

\section{Section 3 - Preparation of lysate}

Table S3. Components included in the cell-free lysate protein expression reaction mixture.

\begin{tabular}{|c|c|c|c|}
\hline Component & $\begin{array}{l}\text { Standard } \\
\text { Reaction }\end{array}$ & $\begin{array}{l}\text { Spermidine } \\
\text { Reaction }\end{array}$ & $\begin{array}{c}\text { Final } \\
\text { Concentration }\end{array}$ \\
\hline $\begin{array}{l}1 \text { M Hepes-KOH Buffer } \\
(\mathrm{pH} 8.2)\end{array}$ & $5.7 \mu \mathrm{l}$ & $5.7 \mu \mathrm{l}$ & $57 \mathrm{mM}$ \\
\hline $50 \mathrm{mM}$ ATP & $2.4 \mu 1$ & $2.4 \mu 1$ & $1.2 \mathrm{mM}$ \\
\hline $50 \mathrm{mM} \mathrm{CTP}$ & $1.7 \mu 1$ & $1.7 \mu 1$ & $0.85 \mathrm{mM}$ \\
\hline $50 \mathrm{mM}$ GTP & $1.7 \mu 1$ & $1.7 \mu \mathrm{l}$ & $0.85 \mathrm{mM}$ \\
\hline $50 \mathrm{mM}$ UTP & $1.7 \mu 1$ & $1.7 \mu 1$ & $0.85 \mathrm{mM}$ \\
\hline $500 \mathrm{mM}$ DTT & $0.4 \mu 1$ & $0.4 \mu 1$ & $2 \mathrm{mM}$ \\
\hline $\begin{array}{l}10 \mathrm{mg} / \mathrm{ml} \text { E. coli total } \\
\text { tRNA mixture } \\
\text { (from strain MRE600) }\end{array}$ & $1.7 \mu 1$ & $1.7 \mu 1$ & $0.17 \mathrm{mg} / \mathrm{ml}$ \\
\hline $15 \mathrm{mM}$ cAMP & $4.27 \mu 1$ & $4.27 \mu 1$ & $0.64 \mathrm{mM}$ \\
\hline 2M Potassium Glutamate & $4.5 \mu 1$ & $4.5 \mu 1$ & $90 \mathrm{mM}$ \\
\hline $2 \mathrm{M}$ Ammonium Acetate & $4 \mu 1$ & $4 \mu 1$ & $80 \mathrm{mM}$ \\
\hline $1 \mathrm{M}$ Magnesium Acetate & $1.2 \mu 1$ & $1.2 \mu 1$ & $12 \mathrm{mM}$ \\
\hline $\begin{array}{l}1 \mathrm{mg} / \mathrm{ml} \text { Folinic Acid } \\
\text { (L-5-formyl-5,6,7,8- } \\
\text { tetrahydrofolic acid) }\end{array}$ & $3.4 \mu 1$ & $3.4 \mu \mathrm{l}$ & $34 \mu \mathrm{g} / \mathrm{ml}$ \\
\hline Each of 20 Amino Acids & $17.98 \mu 1$ & $17.98 \mu 1$ & $1.5 \mathrm{mM} / \mathrm{AA}$ \\
\hline $20 \%$ PEG (8000) & $10 \mu 1$ & N/A & $2 \%$ \\
\hline $\begin{array}{l}1 \text { M Creatine Phosphate } \\
\text { (CP) }\end{array}$ & $6.7 \mu 1$ & $6.7 \mu 1$ & $67 \mathrm{mM}$ \\
\hline $\begin{array}{l}500 \mu \mathrm{g} / \mathrm{ml} \text { Creatine } \\
\text { Kinase }(\mathrm{CK})\end{array}$ & $0.64 \mu 1$ & $0.64 \mu 1$ & $3.2 \mu \mathrm{g} / \mathrm{ml}$ \\
\hline $\begin{array}{l}\text { pIVEX 2.3d-Gene of } \\
\text { Interest }(500 \mu \mathrm{g} / \mathrm{ml})\end{array}$ & $1.34 \mu 1$ & $1.34 \mu 1$ & $6.7 \mu \mathrm{g} / \mathrm{ml}$ \\
\hline S12 E. coli Lysate $-2 X Y T$ & $27 \mu 1$ & $27 \mu 1$ & $27 \%(\mathrm{v} / \mathrm{v})$ \\
\hline $100 \mathrm{mM}$ M Spermidine & N/A & $1.5 \mu 1$ & $1.5 \mathrm{mM}$ \\
\hline Nuclease-Free Water & $3.67 \mu 1$ & $12.17 \mu 1$ & To $100 \mu 1$ \\
\hline
\end{tabular}




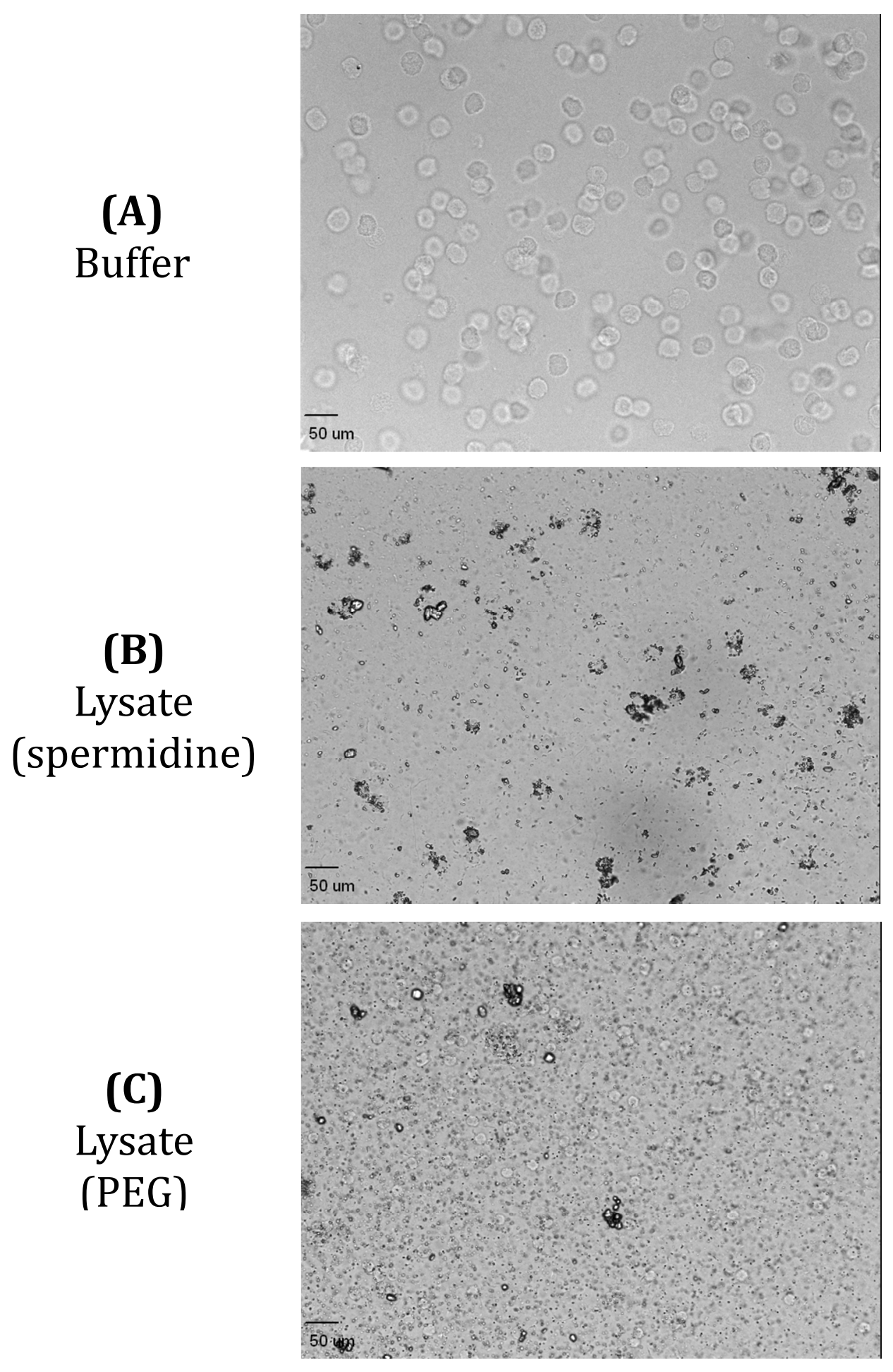

Figure S2. Optical microscopy showing the effects of incubation in different lysates on P-gel microgels compared to their original morphology in buffer ( $10 \mathrm{mM}$ Tris, 50 $\mathrm{mM} \mathrm{NaCl}, \mathrm{pH}$ 7.5). 


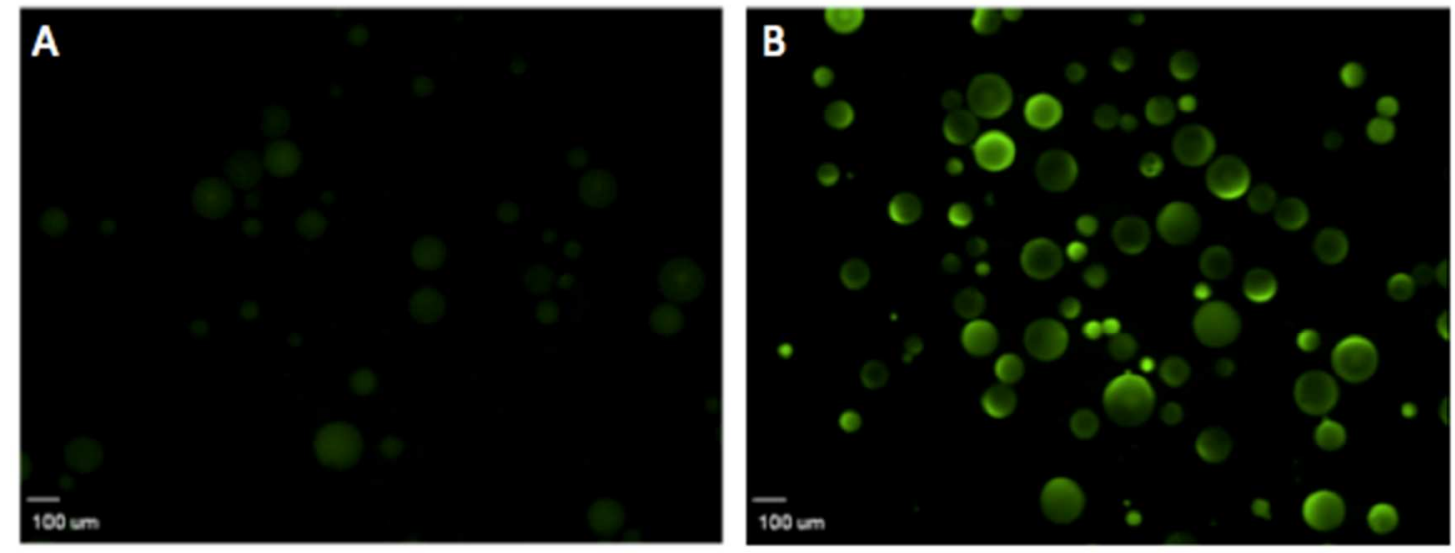

Figure S3. Agarose-NTA-Ni ${ }^{2+}$ (Qiagen) resin beads incubated with wtGFP-6His in (A) E. coli cell-free lysate containing DTT and PEG and (B) cell-free lysate without DTT and PEG.

\section{Section 4 - wtGFP standard}

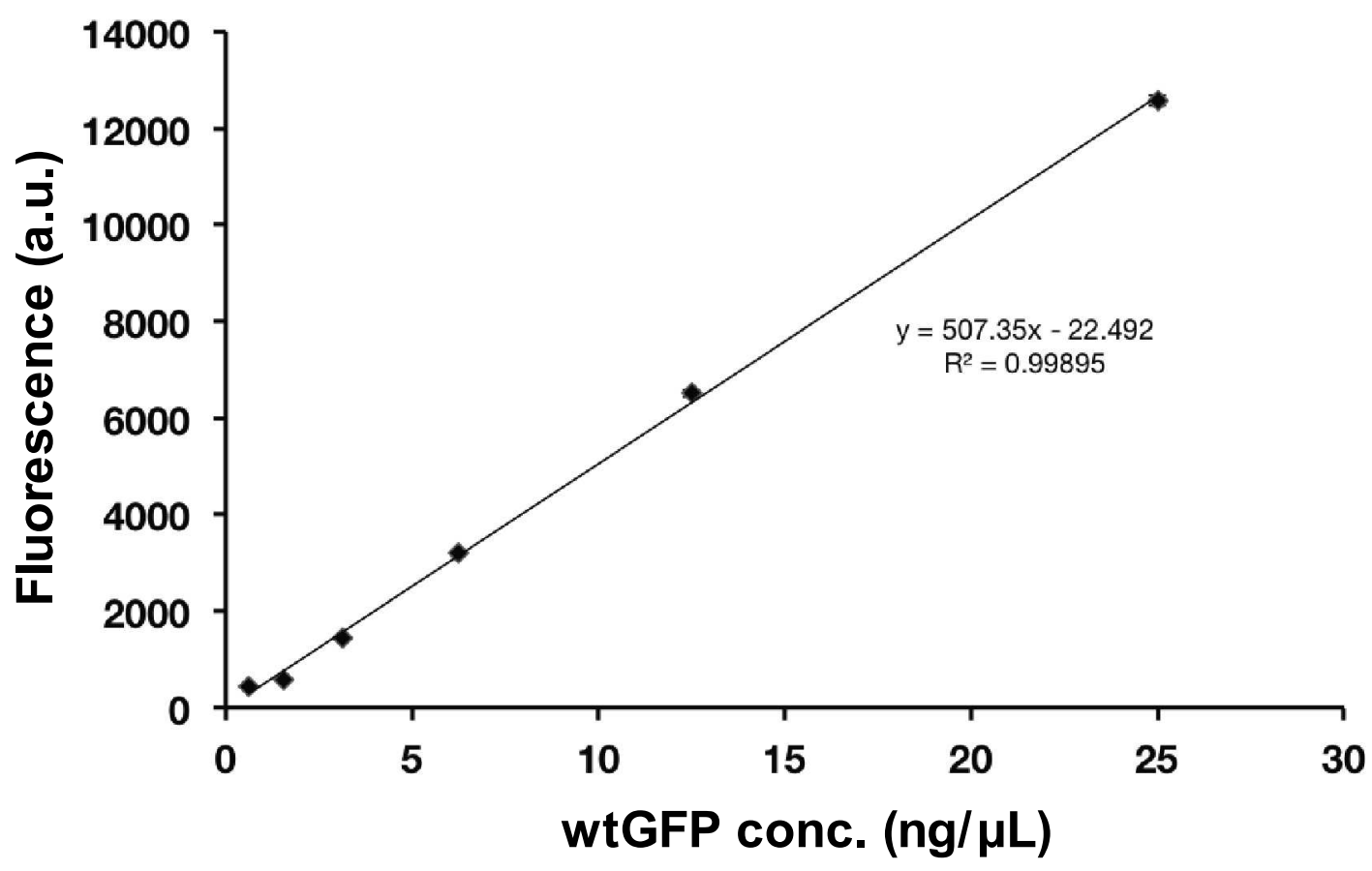

Figure S4: wtGFP standard produced from N-His tagged wtGFP from ThermoFisher, based on 3 repetitions. 


\section{Section 5 - Maleimide-C3-NTA functionalization of oligonucleotides}<smiles>O=C([O-])CN(CC(=O)O)[C@@H](CCCCNC(=O)CCCN1C(=O)C=CC1=O)C(=O)[O-]</smiles>

Figure S5. Chemical structure of maleimido-C3-NTA (MC3N) from Dojindo Molecular Technologies, Inc. The maleimide group is included on the right side of the structure while the nickel-chelating moiety nitrilotriacetic acid (NTA) is on the left.

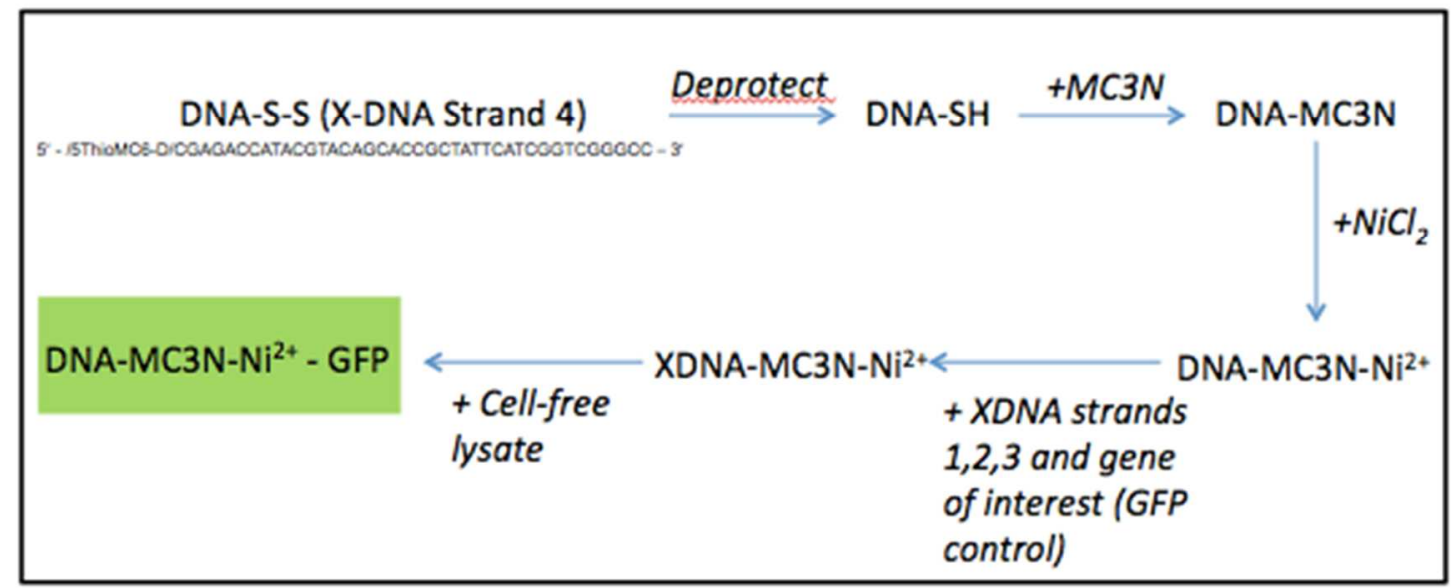

Figure S6. Overview of the MC3N functionalization procedure.

\section{Confirmation of MC3N functionalization}

Mass spectroscopy data (Figure S5) was acquired by an AB/Sciex (Foster City, CA USA) 4000 Q Trap outfitted with the Turbo Ion Spray source. The instrument was 
operated in negative ion, enhanced (EMS) mode scanning at $4000 \mathrm{amu} / \mathrm{sec}$ from m/z 400-1800Da. The samples were diluted to $250 \mu \mathrm{l}$ in $50 \%$ acetonitrile/water and infused directly into the ion source at $5 \mu \mathrm{l} /$ minute. The Total Ion Chromatogram (TIC) was acquired using MCA (Multiple Chromatogram Addition) until the base peak signal reached at least $8.0 \mathrm{e} 6$ counts/sec. Further parameters for operation are shown in Table S4. Figure S7 shows the MC3N functionalization was successful, where adjacent, highest abundance ions in the charge envelope were selected and deconvoluted using Analyst 1.4.2 software (AB/Sciex) to obtain the molecular weight of the dominant species.
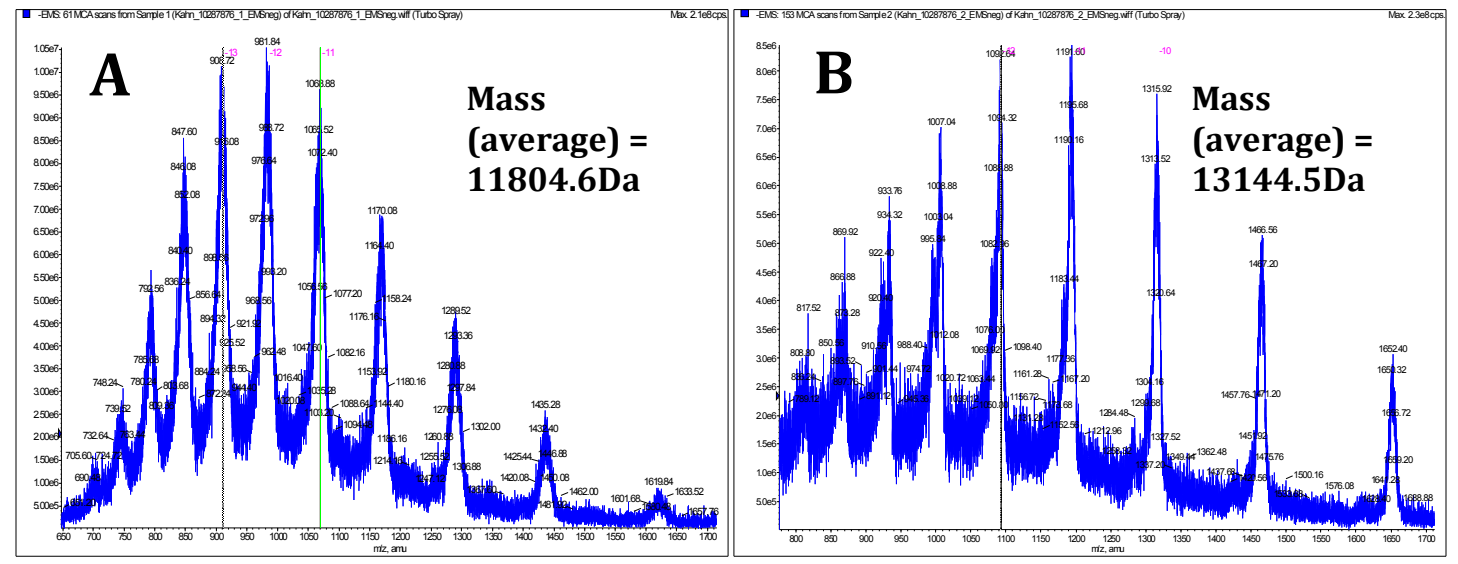

Figure S7. Mass spectroscopy results for A.) unmodified X-DNA strand 4 B.) MC3Nmodified strand 4.

Table S4. Operating conditions for mass spectrometer.

\begin{tabular}{|l|l|}
\hline Curtain Gas (CUR) & 30.0 (arbitrary units) \\
\hline Ion Spray Voltage (IS) & $-4200 \mathrm{~V}$ \\
\hline Collision Gas (CAD) & Low \\
\hline Interface Temperature (TEM) & $200^{\circ} \mathrm{C}$ \\
\hline Gas 1 (GS1) & 15.0 (arbitrary units) \\
\hline Gas 2 (GS2) & 20.0 (arbitrary units) \\
\hline Declustering Potential (DP) & $-150 \mathrm{~V}$ \\
\hline Collision Energy (CE) & $-5.0 \mathrm{~V}$ \\
\hline
\end{tabular}




\section{Section 6 - FACS control}

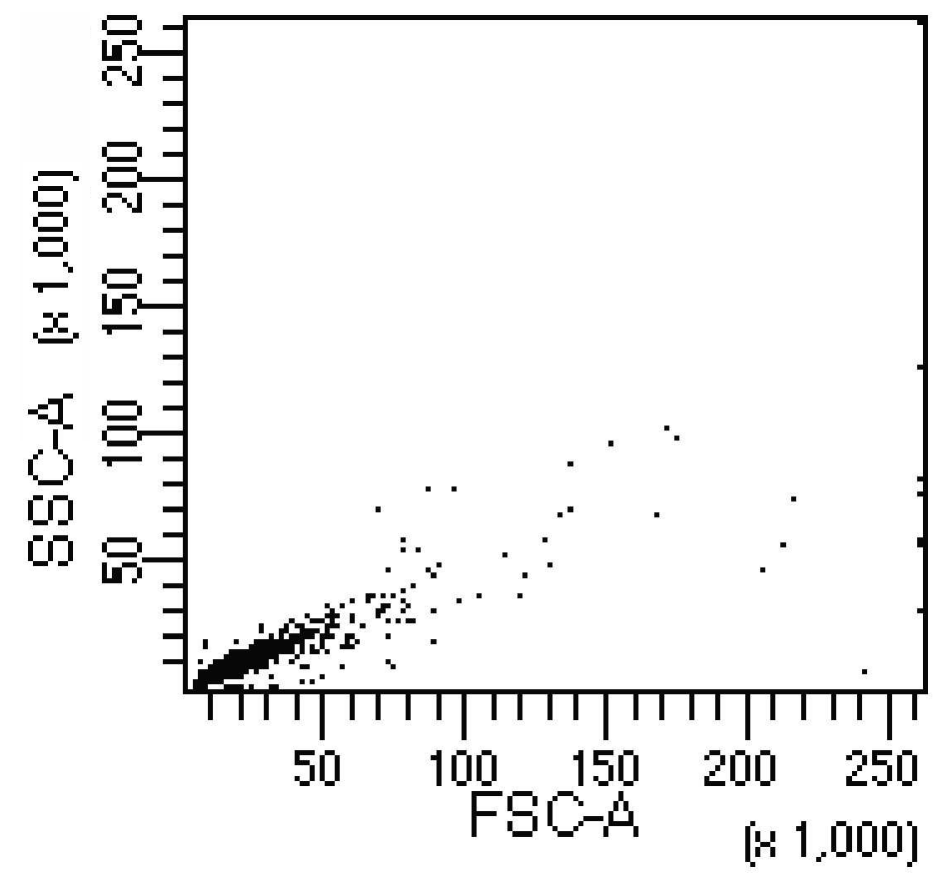

Figure S8: Scatter plot demonstrating showing the side scatter and forward scattering profile of MC3N-P-gel microdroplets coated with His-tagged wtGFP. 


\section{Section 7 - Psoralen crosslinking}

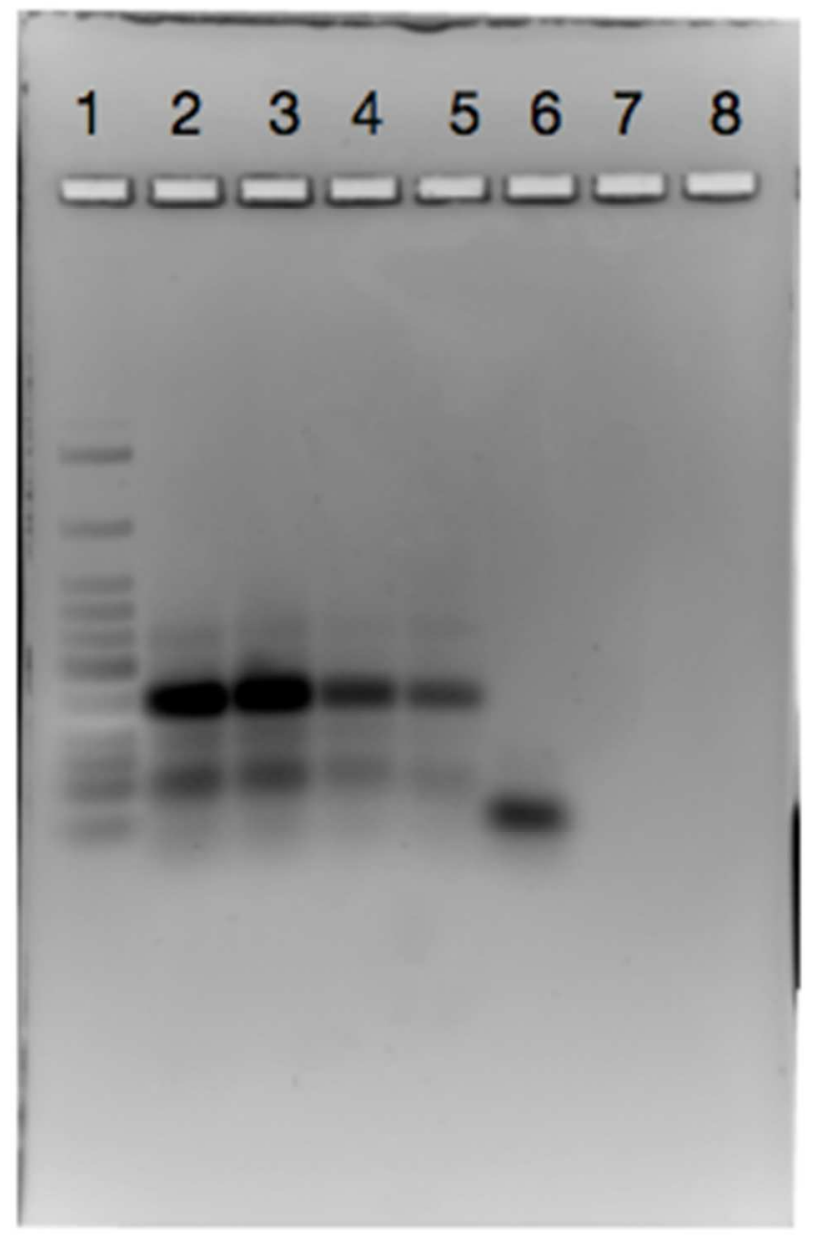

Figure S9. 2.5\% agarose gel demonstrating of hybridization efficiency for the redesigned X-oligos to form branched X-DNA. Lane 1: NEB LMW Ladder. Lane 2: Original (non-optimized for psoralen crosslinking) X-DNA. Lane 3: Repeat of previous. Lane 4: Redesigned X-DNA. Lane 5: Repeat of previous. Lane 6: Strand 4 from X-DNA. 